\title{
Case Series: Minocycline-Associated Thyroiditis
}

\author{
Kate Millington $^{\mathrm{a}}$ Alexandra Charrow $^{\mathrm{b}}$ Jessica Smith ${ }^{\mathrm{a}}$ \\ ${ }^{a}$ Division of Endocrinology, Boston Children's Hospital, Boston, MA, USA; ${ }^{\mathrm{b}}$ Department of Dermatology, \\ Brigham and Women's Hospital, Boston, MA, USA
}

\section{Established Facts}

- Several medications are known to cause non-autoimmune thyroiditis.

- Minocycline causes thyroid pigmentation "black thyroid" which is thought to be a benign occurrence.

\section{Novel Insights}

- Minocycline is associated with non-autoimmune thyroiditis.

- Clinicians prescribing minocycline should monitor patients for symptoms of thyroid dysfunction.

\section{Keywords}

Thyroiditis $\cdot$ Minocycline $\cdot$ Tetracycline $\cdot$ Acne

\begin{abstract}
Introduction: Minocycline, a member of the tetracycline class of antibiotics, has been associated with benign thyroid pigmentation but reports of thyroid dysfunction are sparse. Methods: Cases were selected via an inquiry of the electronic medical records for patients with thyroid dysfunction and the use of a tetracycline antibiotic. Non-autoimmune thyroiditis was defined as abnormally low or suppressed thyroid-stimulating hormone (TSH, $<0.3 \mu \mathrm{lU} / \mathrm{mL})$, elevated free
\end{abstract}

\section{KARGER}

(C) 2019 S. Karger AG, Basel

karger@karger.com www.karger.com/hrp thyroxine or total thyroxine, and undetectable antithyroid antibodies. Results: Nine cases of thyroiditis without autoimmunity were identified out of 423 reviewed patients. Cases of thyroiditis occurred in adolescents ages 14-17 years who had been taking minocycline for 6 months to 4 years. In all cases, minocycline was prescribed for the treatment of acne. Four of the 9 received treatment for thyrotoxicosis with a $\beta$-blocker (in 3 cases) and/or antithyroid drug (in 2 cases). Thyroiditis was symptomatic in all but one individual who presented with painless goiter. All thyroiditis was transient and resolved after a median of 4.5 months (range 2-5 months). In one case, thyroiditis was followed by transient hypothyroidism. Discussion: Minocycline is known to cause 
thyroid abnormalities, although it has not been definitively linked to thyroid dysfunction. Here, we report 9 cases of nonautoimmune thyroiditis in adolescents receiving minocycline for acne. We recommend that minocycline exposure be considered in the differential diagnosis for thyroiditis and that patients receiving minocycline be counseled regarding the risk of thyroid dysfunction.

(c) 2019 S. Karger AG, Base

\section{Introduction}

Minocycline, a tetracycline antibiotic, is commonly prescribed for acne vulgaris (acne) in adolescents and adults. Minocycline has several well-documented adverse effects including an association with autoimmunity, in particular autoimmune hepatitis, drug-induced lupus, and vasculitis [1]. With long-term use, it also has a propensity to deposit pigment (both iron and hemosiderin) throughout the bone, skin, and soft tissue [2] . Pigmentation of the thyroid gland, i.e., "black thyroid," has been noted on autopsy and postoperative pathology in patients receiving minocycline [2-4]. The early reports of black thyroid did not describe any disturbance in thyroid function [3, 5-7]; however, 2 later cases reported an association with hypothyroidism [8]. There have been reports of thyroiditis associated with minocycline treatment in adults, although these were in association with severe autoimmune conditions and/or with evidence of thyroid autoimmunity $[9,10]$. There is only one previous report of the development of thyroiditis in patients receiving minocycline in the absence of underlying thyroid autoimmunity [11]. We report an additional 9 cases of minocycline associated non-autoimmune thyroiditis.

\section{Methods}

The Boston Children's Hospital Electronic Medical Record was queried using the ICD-9 or ICD-10 code for thyroid disorder and tetracycline antibiotics. Results were limited to those who presented to the outpatient endocrine clinic between 1 January 2000 and 1 July 2018. Patients with thyroid cancer, congenital hypothyroidism, thyroid nodules, trisomy 21 , or type 1 diabetes mellitus were excluded. Additionally, patients who were taking medications known to affect thyroid function such as lithium salts, amiodarone, antiseizure drugs, or who had evidence of thyroid autoimmunity as reflected by the presence of thyroperoxidase (TPO) or thyroglobulin (Tg) antibodies, were excluded. Patients were included if they had levels of thyroid-stimulating hormone (TSH), thyroxine (T4), or free thyroxine (free T4) outside of the reference range at any time. Medical record abstraction was performed for subjects to confirm that they met the inclusion criteria, and also to document symptoms, tetracycline antibiotic use, and laboratory findings.

\section{Results}

Four hundred and twenty-three patients were reviewed, 23 of whom met the inclusion criteria. Of these, 10 had evidence of subclinical hyperthyroidism defined as suppressed TSH $<0.3 \mu \mathrm{IU} / \mathrm{mL}$, normal free T4, and total tri-iodothyronine (T3); 3 had subclinical hypothyroidism (TSH $>5.7 \mu \mathrm{IU} / \mathrm{mL}$, normal free $\mathrm{T} 4$, and total T3); and 1 had primary hypothyroidism. Nine patients had thyroiditis, and their cases are summarized here (Table 1).

\section{Case 1}

A 17-year-old male developed tachycardia, palpitations, myalgias, insomnia, and restlessness approximately 11 months after starting oral minocycline $200 \mathrm{mg}$ daily for the treatment of acne. There was no family history of thyroid dysfunction, and the patient was not taking other medications. On examination, the thyroid was normal in size and texture, and without evidence of nodularity. Serum TSH concentration was $<0.005 \mu \mathrm{IU} / \mathrm{mL}$ (reference range $0.7-5.7 \mu \mathrm{IU} / \mathrm{mL}$ ), Free T4 was elevated at $5.21 \mathrm{ng} /$ $\mathrm{dL}$ (reference range $0.8-1.9 \mathrm{ng} / \mathrm{dL}$ ) and total T3 was elevated at $420 \mathrm{ng} / \mathrm{dL}$ (reference range $80-210 \mathrm{ng} / \mathrm{dL}$ ). AntiTPO, anti-Tg, and thyrotropin receptor antibodies (TRAbs) were undetectable. Thyrotropin-stimulating immunoglobulins (TSI) were likewise negative. Scintigraphy with I-123 demonstrated low uptake ( $4 \%$ at $4 \mathrm{~h}$ and $2 \%$ at $24 \mathrm{~h}$ ) consistent with acute thyroiditis. The patient was treated with $\beta$-blockade for symptomatic tachycardia. Upon discontinuation of minocycline, his symptoms resolved in 1 month; restoration of euthyroidism occurred by 3 months.

\section{Case 2}

A 16-year-old male presented with weight loss, fatigue, palpitations, and diarrhea while receiving oral minocycline $200 \mathrm{mg}$ daily for 4 years for acne. There was no family history of thyroid dysfunction. His thyroid was of normal size, texture, and without evidence of nodularity. TSH was suppressed at $<0.005 \mu \mathrm{IU} / \mathrm{mL}$ (reference range $0.358-3.74 \mu \mathrm{IU} / \mathrm{mL}$ ) and free T4 was elevated at $2.13 \mathrm{ng} /$ dL (reference range $0.76-1.46 \mathrm{ng} / \mathrm{dL}$ ). Anti-TPO, anti$\mathrm{Tg}$, and TRAbs antibodies were undetectable. After mi- 
Table 1. Summary of our 9 cases of minocycline-associated thyroiditis

\begin{tabular}{|c|c|c|c|c|c|c|c|c|}
\hline Age & Sex & $\begin{array}{l}\text { Treatment } \\
\text { duration; } \\
\text { dose }\end{array}$ & Indication & $\mathrm{Ab}$ & $\begin{array}{l}\text { Symptoms } \\
\text { and signs }\end{array}$ & Evidence of thyroiditis & Treatment & $\begin{array}{l}\text { Time to } \\
\text { euthyroidism }\end{array}$ \\
\hline 17 years & M & $\begin{array}{l}11 \text { months; } \\
200 \mathrm{mg} / \text { day }\end{array}$ & Acne & Neg & $\begin{array}{l}\text { Tachycardia, palpitations, } \\
\text { myalgias, insomnia }\end{array}$ & $\begin{array}{l}\text { TSH } 0.005(\mathrm{nl} 0.7-5.7 \mu \mathrm{IU} / \mathrm{mL}) \\
\text { Free T4 } 5.21(\mathrm{nl} 0.8-1.9 \mathrm{ng} / \mathrm{dL}) \\
\text { Total T3 } 420(\mathrm{nl} 80-210 \mathrm{ng} / \mathrm{dL}) \\
\text { Radioiodine uptake scan } 2 \%\end{array}$ & Propranolol & 3 months \\
\hline 16 years & M & $\begin{array}{l}4 \text { years; } \\
200 \mathrm{mg} / \mathrm{day}\end{array}$ & Acne & Neg & $\begin{array}{l}\text { Weight loss, fatigue, } \\
\text { palpitations, diarrhea }\end{array}$ & $\begin{array}{l}\text { TSH } 0.005(\mathrm{nl} 0.36-3.7 \mu \mathrm{IU} / \mathrm{mL}) \\
\text { Free T4 } 2.13(\mathrm{nl} 0.76-1.46 \mathrm{ng} / \mathrm{dL})\end{array}$ & None & 5 months \\
\hline 15 years & $\mathrm{F}$ & Unknown & Acne & Neg & $\begin{array}{l}\text { Mood lability, tremors, } \\
\text { hypertension, } \\
\text { hyperreflexia, goiter }\end{array}$ & $\begin{array}{l}\text { TSH } 0.005(\mathrm{nl} 0.7-5.7 \mu \mathrm{IU} / \mathrm{mL}) \\
\text { Total T4 } 11.3(\mathrm{nl} 5.2-10.7 \mu \mathrm{g} / \mathrm{dL}) \\
\text { Total T3 } 189(\mathrm{nl} 86-153 \mathrm{ng} / \mathrm{dL})\end{array}$ & None & 4 months \\
\hline 16 years & M & $\begin{array}{l}15 \text { months; } \\
100 \mathrm{mg} / \text { day }\end{array}$ & Acne & Neg & Weight loss, palpitations & $\begin{array}{l}\text { TSH } 0.006(\mathrm{nl} 0.37-5.22 \mu \mathrm{IU} / \mathrm{mL}) \\
\text { Free T4 } 1.91(\mathrm{nl} 0.7-1.9 \mathrm{ng} / \mathrm{dL})\end{array}$ & Propranolol & 3 months \\
\hline 17 years & $\mathrm{F}$ & $\begin{array}{l}12 \text { months; } \\
200 \mathrm{mg} / \text { day }\end{array}$ & Acne & Neg & Secondary amenorrhea & $\begin{array}{l}\text { TSH } 0.019(\mathrm{nl} 0.7-5.7 \mu \mathrm{IU} / \mathrm{mL}) \\
\text { Total T4 } 12.5(\mathrm{nl} 4.7-12.4 \mu \mathrm{g} / \mathrm{dL}) \\
\text { THBR } 1.22(\mathrm{nl} 0.77-1.16)\end{array}$ & None & 2 months \\
\hline 17 years & $\mathrm{F}$ & $\begin{array}{l}6 \text { months; } \\
100 \mathrm{mg} / \mathrm{day}\end{array}$ & Acne & Neg & Fatigue & $\begin{array}{l}\text { TSH } 0.006(\mathrm{nl} 0.7-5.7 \mu \mathrm{IU} / \mathrm{mL}) \\
\text { Free T4 } 2.34(\mathrm{nl} 0.8-1.9 \mathrm{ng} / \mathrm{dL}) \\
\text { Total T3 } 194(\mathrm{nl} 80-210 \mathrm{ng} / \mathrm{dL})\end{array}$ & None & 5 months \\
\hline 15 years & $\mathrm{F}$ & $\begin{array}{l}8 \text { months; } \\
100 \mathrm{mg} / \text { day }\end{array}$ & Acne & Neg & Weight loss, fatigue & $\begin{array}{l}\text { TSH } 0.020(\mathrm{nl} 0.27-4.2 \mu \mathrm{IU} / \mathrm{mL}) \\
\text { Total T4 } 15.6(\mathrm{nl} 4.6-12.0 \mu \mathrm{g} / \mathrm{dL})\end{array}$ & Methimazole & 5 months \\
\hline 14 years & $\mathrm{F}$ & $\begin{array}{l}8 \text { months; } \\
\text { unknown }\end{array}$ & Acne & Neg & $\begin{array}{l}\text { Anxiety, weight loss, } \\
\text { sleep difficulties }\end{array}$ & $\begin{array}{l}\text { TSH } 0.013(\mathrm{nl} 0.7-5.7 \mu \mathrm{IU} / \mathrm{mL}) \\
\text { Free T4 } 4.82(\mathrm{nl} 0.8-1.9 \mathrm{ng} / \mathrm{dL}) \\
\text { Total T3 } 223(\mathrm{nl} 80-210 \mathrm{ng} / \mathrm{dL}) \\
\text { Radioiodine uptake scan } 3 \%\end{array}$ & $\begin{array}{l}\text { Methimazole, } \\
\text { atenolol }\end{array}$ & 5 months \\
\hline 16 years & $\mathrm{F}$ & $\begin{array}{l}\text { Unknown; } \\
150 \mathrm{mg} / \text { day }\end{array}$ & Acne & Neg & None & $\begin{array}{l}\text { TSH } 0.030(\mathrm{nl} 0.34-5.6 \mu \mathrm{IU} / \mathrm{mL}) \\
\text { Rotal T4 } 14.4(\mathrm{nl} 5.0-12.2 \mu \mathrm{g} / \mathrm{dL}) \\
\text { Free T4 } 3.19(\mathrm{nl} 0.54-1.64 \mathrm{ng} / \mathrm{dL})\end{array}$ & None & 5 months \\
\hline
\end{tabular}

M, male; F, female; Ab, anti-Tg and anti-TPO antibodies; Neg, negative; TSH, thyroid-stimulating hormone; T4, thyroxine; nl, normal.

nocycline was discontinued, thyrotoxicosis improved in 1 week, with total T4 9.2 $\mu \mathrm{g} / \mathrm{dL}$ (reference range 4.7-12.4 $\mu \mathrm{g} / \mathrm{dL}$ ), TSH-binding ratio (THBR) 1.11 (reference range $0.88-1.08$ ), and T3 $132 \mathrm{ng} / \mathrm{dL}$ (reference range 80-210 $\mathrm{ng} / \mathrm{dL}$ ). TSH remained suppressed for 2 months, after which time the patient experienced transient subclinical hypothyroidism, TSH $10.43 \mu \mathrm{IU} / \mathrm{mL}$ (reference range $0.27-4.2 \mu \mathrm{IU} / \mathrm{mL}$ ) and free T40.92 $\mathrm{ng} / \mathrm{dL}$ (reference range $0.9-1.7 \mathrm{ng} / \mathrm{dL}$ ). Euthyroidism was restored 5 months after discontinuation of minocycline.

\section{Case 3}

A 15-year-old female was found to be hypertensive, tremulous, and hyperreflexic during evaluation for mood lability. She had been taking oral minocycline for acne for an unknown duration as well as sertraline for depression and albuterol for asthma. The thyroid was palpated at 1.5 times (20-25 g) the normal size without evidence of a fo- cal nodule. There was a history of hypothyroidism in the patient's mother. Serum TSH concentration was $<0.005$ $\mu \mathrm{IU} / \mathrm{mL}$ (reference range $0.7-5.7 \mu \mathrm{IU} / \mathrm{mL}$ ). T4 and T3 were both elevated at $11.3 \mu \mathrm{g} / \mathrm{dL}$ (reference range 5.2$10.7 \mu \mathrm{g} / \mathrm{dL}$ ) and $189 \mathrm{ng} / \mathrm{dL}$ (reference range $86-153 \mathrm{ng} /$ $\mathrm{dL}$ ), respectively. Anti-TPO, anti-Tg, TRAbs, and TSI antibodies were not detectable. Upon discontinuation of the minocycline, the thyrotoxicosis resolved, and euthyroidism was restored by 4 months.

\section{Case 4}

Approximately 15 months after starting treatment with oral minocycline $100 \mathrm{mg}$ daily for acne, a 16-yearold male experienced palpitations and weight loss. His thyroid was normal in size and texture without appreciable nodules. Upon evaluation, his serum TSH was suppressed to $0.006 \mu \mathrm{IU} / \mathrm{mL}$ (reference range $0.370-5.22$ $\mu \mathrm{IU} / \mathrm{mL}$ ) and free T4 was mildly elevated at $1.91 \mathrm{ng} / \mathrm{dL}$ 
(reference range 0.7-1.9 ng/dL). Anti-TPO, anti-Tg, TRAbs, and TSI were negative. He was treated symptomatically with $\beta$-blockade for heart palpitations. The thyrotoxicosis resolved 3 months after the discontinuation of minocycline.

\section{Case 5}

A 17-year-old female presented with biochemical evidence of thyrotoxicosis during an evaluation for secondary amenorrhea. She had begun treatment with oral minocycline $200 \mathrm{mg}$ daily for acne 1 year earlier. Her thyroid was smooth, not enlarged, and without nodularity. TSH was suppressed to $0.019 \mu \mathrm{IU} / \mathrm{mL}$ (reference range 0.7-5.7 $\mu \mathrm{IU} / \mathrm{mL}$ ). T4 was elevated at $12.5 \mu \mathrm{g} / \mathrm{dL}$ (reference range 4.7-12.4 $\mu \mathrm{g} / \mathrm{dL})$ with THBR 1.22 (0.77-1.16). Anti-TPO, anti-Tg, TRAbs, and TSI were negative. Thyrotoxicosis resolved within 2 months of discontinuation of minocycline treatment. The patient was started on oral contraceptive medication and experienced regular menses.

\section{Case 6}

A 17-year-old female presented for evaluation of fatigue, at which time she was found to have a suppressed $\mathrm{TSH}$ at $0.006 \mu \mathrm{IU} / \mathrm{mL}$ (reference range $0.7-5.7 \mu \mathrm{IU} / \mathrm{mL}$ ) and elevated free T4 of $2.34 \mathrm{ng} / \mathrm{dL}$ (reference range 0.80 1.9). On exam, her thyroid was normal in size, texture, and without nodules. The T3 was normal at $194 \mathrm{ng} / \mathrm{dL}$ (reference range $80-210 \mathrm{ng} / \mathrm{dL}$ ). Six months prior, she had started on oral minocycline $100 \mathrm{mg}$ daily for acne. Anti-TPO, anti-Tg, and TRAbs were negative. Thyrotoxicosis resolved 5 months after the discontinuation of minocycline.

\section{Case 7}

A 15-year-old female presented with weight loss and fatigue 8 months after initiating oral minocycline $100 \mathrm{mg}$ daily for acne. There was a family history of hypothyroidism in the patient's mother and maternal grandmother. Her thyroid was smooth in texture, not enlarged, and without nodularity. TSH was suppressed at $0.020 \mu \mathrm{IU} / \mathrm{mL}$ (reference range $0.27-4.2 \mu \mathrm{IU} / \mathrm{mL}$ ) and $\mathrm{T} 4$ was elevated at $15.6 \mu \mathrm{g} / \mathrm{dL}$ (reference range $4.6-12.0 \mu \mathrm{g} / \mathrm{dL}$ ). AntiTPO, anti-Tg, TRAbs, and TSI were negative. Minocycline was discontinued, and antithyroid drug (methimazole) treatment was started at $10 \mathrm{mg} 3$ times daily. After 5 months, the patient's symptoms improved, and methimazole was discontinued. The result of follow-up thyroid function testing was within normal limits. Fifteen months later she developed subclinical hypothyroidism, which spontaneously resolved after 2 years.

Thyroiditis and Minocycline

\section{Case 8}

A 14-year-old female presented with thyrotoxicosis after evaluation for anxiety, weight loss, and insomnia. Eight months prior, she had begun treatment with oral minocycline for acne. There was no family history of thyroid disease. Her thyroid was smooth, not enlarged, and without palpable nodules. TSH was suppressed 0.013 $\mu \mathrm{IU} / \mathrm{mL}$ (reference range $0.7-5.7 \mu \mathrm{IU} / \mathrm{mL}$ ). Free T4 and Total T3 were elevated at $4.82 \mathrm{ng} / \mathrm{dL}$ (reference range $0.8-$ $1.9 \mathrm{ng} / \mathrm{dL}$ ) and $223 \mathrm{ng} / \mathrm{dL}$ (reference range 80-210 ng/ dL), respectively. Anti-TPO, anti-Tg, and TRAbs were negative. The patient was treated with the antithyroid drug methimazole $10 \mathrm{mg}$ twice daily and $\beta$-blockade for 1 month. Scintigraphy with I-123 was performed 10 days after the discontinuation of methimazole and demonstrated low uptake ( $3 \%$ at $4 \mathrm{~h}$ and $1 \%$ at $24 \mathrm{~h}$ ), consistent with thyroiditis. Her thyrotoxic symptoms improved within 1 month, and the restoration of euthyroidism was documented 5 months later.

\section{Case 9}

A 16-year-old female presented with biochemical evidence of thyrotoxicosis during an evaluation for possible goiter. She was taking oral minocycline $150 \mathrm{mg}$ daily for acne for an unknown duration. There was no family history of thyroid dysfunction. On examination, her thyroid was smooth, not enlarged, and had no nodules. TSH was suppressed $0.03 \mu \mathrm{IU} / \mathrm{mL}$ (reference range 0.34-5.6 $\mu \mathrm{IU} /$ $\mathrm{mL}$ ), T4 was elevated at $14.4 \mu \mathrm{g} / \mathrm{dL}$ (reference range 5.0 $12.2 \mu \mathrm{g} / \mathrm{dL}$ ) and free T4 $3.19 \mathrm{ng} / \mathrm{dL}$ (reference range $0.54-$ $1.64 \mathrm{ng} / \mathrm{dL}$ ). Anti-TPO and anti-Tg were negative. Minocycline was discontinued. After 2 months, free T4 had improved to $0.96 \mathrm{ng} / \mathrm{dL}$ (reference range $0.8-1.9 \mathrm{ng} / \mathrm{dL}$ ), although TSH remained $<0.01 \mu \mathrm{IU} / \mathrm{mL}$ (reference range $0.7-5.7 \mu \mathrm{IU} / \mathrm{mL}$ ) for 5 months.

\section{Discussion}

We report here 9 cases of thyroiditis in adolescents receiving minocycline for the treatment of acne. Non-autoimmune thyroiditis associated with tetracycline use has been reported, and this is the largest series to date [11].

Tetracycline antibiotics were discovered in the early 1940s, and the first in the class, aureomycin, was approved by the US Food and Drug Administration (FDA) for clinical use in December 1948. Following the publication of the tetracycline class molecular structure in 1952, synthetic modifications of the core molecule produced compounds with increased stability and efficacy includ-

Horm Res Paediatr 2019;92:276-283 
ing doxycycline (FDA-approved in 1967), and minocycline (FDA-approved in 1971) [12,13]. Tetracyclines exert their bacteriostatic effect by binding to a highly conserved site within the $30 \mathrm{~S}$ ribosomal subunit, interfering with transfer-RNA docking, and thus preventing protein translation [14]. Oral tetracyclines, chiefly doxycycline and minocycline, are routinely used in the treatment of acne for their antibacterial as well as anti-inflammatory properties. Minocycline is the only FDA-approved antibiotic for the treatment of moderate to severe inflammatory acne and is considered the first-line therapy in combination with a topical retinoid $[15,16]$.

Minocycline has the greatest lipid solubility of drugs in the tetracycline class, leading to a greater ability to penetrate tissues and a more variable half-life. After prolonged use, the half-life of minocycline can vary from 12 to $23 \mathrm{~h}$, due to the release of drug by bodily lipids $[17,18]$. In a study on patients with a minocycline-induced drug rash with eosinophilia and systemic symptoms (DRESS), 6 of the 8 patients had detectable serum levels of minocycline for up to 17 months after cessation of the drug [19].

Pigmentation of multiple tissues, including the skin, teeth, and bone is a well-known adverse effect of tetracyclines, minocycline in particular [2]. Pigmentation of the thyroid, so-called "black thyroid," was first reported in humans in 1976 after several reports of this phenomenon in animals $[3,20]$. Electron microscopic analysis of the pigment revealed its presence both in colloid and within lysosomal structures in follicular epithelial cells [3, 7]. In animal studies, thyroid pigmentation by minocycline was prevented by coadministration of propylthiouracil or TSH supplements. Both decreased endogenous TSH production and led to the hypothesis that the pigmentation was linked to the synthesis of TSH [20]. This observation was further supported by studies in rats showing that minocycline administration leads to goiter, increased radioactive iodine uptake by the thyroid, and decreased TSH synthesis [21]. Taurog et al. [22] demonstrated that incubation of minocycline with TPO resulted in the oxidation of minocycline and/or its metabolites and the formation of black pigment. In vitro studies with minocycline demonstrated it to be a potent inhibitor of TPO-guided iodination and coupling of mono-iodotyrosine and di-iodotyrosine to form TSH $[22,23]$. In addition to the inhibition of TPO by minocycline, other proposed mechanisms of pigment deposition include (1) the binding of minocycline degradation products with lipofuscin, a normally occurring intracytoplasmic pigment associated with aging, (2) the acceleration and accentuation of lipofuscin development, (3) the accumulation of oxidized metabolites of minocycline, and (4) lysosome dysfunction given the presence of pigment in lysosomal-type structures [7, $8,24,25]$.

"Black thyroid" has been noted in patients after a wide range of tetracycline exposure as well as in those who discontinued the drug. Pigment deposition may occur early in the treatment course and represents a permanent alteration in the thyroid $[4,26]$. The relatively common finding of "black thyroid" and the potential for thyroid dysregulation has led many authors to call for the routine monitoring of thyroid function in patients taking tetracyclines.

Drug-associated thyrotoxicosis has been reported in patients receiving amiodarone, lithium, interferon- $\alpha$, interleukin-2, tyrosine kinase inhibitors, and checkpoint inhibitor immunotherapy. Mechanisms of drug-associated thyrotoxicosis include delivery of an increased iodine load, as is the case in amiodarone-associated thyroiditis, and the release of preformed TSH through direct destruction of thyroid follicular cells and via the induction of thyroid autoimmunity [25, 27-32].

To our knowledge, there are 6 cases reported in the literature of thyrotoxicosis associated with minocycline treatment (Table 2). Three of these were reported by Pollock et al. [11] in 2016 in a study of otherwise healthy adolescents receiving minocycline for the treatment of acne. Another case reported by Benjamin and Calikoglu [33] was a 16-year-old male who also received minocycline for acne. This was confounded by the presence of a lupus-like syndrome, arthritis of the ankles, and positive markers of autoimmunity. After discontinuing minocycline, his thyroid dysfunction and arthritis resolved, and the laboratory tests normalized. Tacon et al. [34] reported a case of a 31-year-old female who presented with antibody-negative thyroiditis and a right-sided nodule. Upon fine-needle aspiration, cytology was suspicious for papillary thyroid carcinoma. The patient proceeded to total thyroidectomy, which revealed a "black thyroid" with histologic evidence of drug-induced thyroiditis similar to that observed with amiodarone exposure [34]. Thyroiditis was noted in association with several cases of DRESS associated with minocycline, although systemic symptoms including fever and rash were also observed in these cases $[9,10]$.

In this case series, we report 9 additional cases of thyroiditis following minocycline treatment for acne. This is the largest reported series to date. Similar to previous cases, these patients developed thyroiditis after a wide range of minocycline exposures. In all cases, thyroiditis resolved 
Table 2. Summary of cases of minocycline-associated non-autoimmune thyroiditis reported in the literature

\begin{tabular}{|c|c|c|c|c|c|c|c|c|c|}
\hline Ref. & $\begin{array}{l}\text { Age, } \\
\text { years }\end{array}$ & Sex & $\begin{array}{l}\text { Treatment } \\
\text { duration; } \\
\text { dose }\end{array}$ & Indication & $\mathrm{Ab}$ & $\begin{array}{l}\text { Symptoms } \\
\text { and signs }\end{array}$ & Evidence of thyroiditis & Treatment & $\begin{array}{l}\text { Time to } \\
\text { euthyroidism }\end{array}$ \\
\hline$[11]$ & 16 & $\mathrm{~F}$ & $\begin{array}{l}\text { Unknown; } \\
200 \text { mg/day }\end{array}$ & Acne & Neg & $\begin{array}{l}\text { Fatigue, headaches, } \\
\text { weakness, diplopia }\end{array}$ & $\begin{array}{l}\text { TSH } 0.013(\mathrm{nl} 0.5-5.5 \mu \mathrm{IU} / \mathrm{mL}) \\
\text { Free T4 } 2.4(\mathrm{nl} 0.9-1.7 \mathrm{ng} / \mathrm{dL}) \\
\text { Total T3 } 253 \text { (nl } 80-160 \mathrm{ng} / \mathrm{dL}) \\
\text { Radioiodine uptake scan } 2.9 \%\end{array}$ & None & Unknown \\
\hline$[11]$ & 16 & $\mathrm{M}$ & $\begin{array}{l}23 \text { months; } \\
200 \mathrm{mg} / \text { day }\end{array}$ & Acne & Neg & $\begin{array}{l}\text { Fatigue, headaches, heat } \\
\text { intolerance, weight loss, } \\
\text { insomnia, palpitations, } \\
\text { diarrhea }\end{array}$ & $\begin{array}{l}\text { TSH }<0.03(\mathrm{nl} 0.36-4.57 \mu \mathrm{IU} / \mathrm{mL}) \\
\text { Free T4 } 7.57(\mathrm{nl} 0.75-1.54 \mathrm{ng} / \mathrm{dL}) \\
\text { Radioiodine uptake scan } 0.3 \%\end{array}$ & $\begin{array}{l}\text { Methimazole, } \\
\text { propranolol }\end{array}$ & Unknown \\
\hline$[11]$ & 16 & $\mathrm{M}$ & $\begin{array}{l}9 \text { months; } \\
200 \mathrm{mg} / \text { day }\end{array}$ & Acne & Neg & Fatigue, heat intolerance & $\begin{array}{l}\text { TSH } 0.01(\mathrm{nl} 0.36-4.20 \mu \mathrm{IU} / \mathrm{mL}) \\
\text { Free T4 } 3.26(\mathrm{nl} 0.7-1.45 \mathrm{ng} / \mathrm{dL}) \\
\text { Radioiodine uptake scan } 0.5 \%\end{array}$ & $\begin{array}{l}\text { Methimazole, } \\
\text { propranolol }\end{array}$ & $\begin{array}{l}\text { Persistent } \\
\text { hypothyroidism }\end{array}$ \\
\hline$[33]$ & 16 & M & $\begin{array}{l}18 \text { months; } \\
100 \mathrm{mg} / \text { day }\end{array}$ & Unknown & Neg & $\begin{array}{l}\text { Tachycardia, } \\
\text { tremulousness, goiter }\end{array}$ & $\begin{array}{l}\text { TSH }<0.05(\mathrm{nl} 0.370-6.0 \mu \mathrm{IU} / \mathrm{mL}) \\
\text { Total T4 } 15(\mathrm{nl} 4.5-12 \mu \mathrm{g} / \mathrm{dL}) \\
\text { Total T3 } 2.8(\mathrm{nl} 1.0-1.7 \mathrm{ng} / \mathrm{mL})\end{array}$ & $\begin{array}{l}\text { Methimazole, } \\
\text { atenolol }\end{array}$ & 4 months \\
\hline$[34]$ & 31 & $\mathrm{~F}$ & $\begin{array}{l}18 \text { months; } \\
100 \mathrm{mg} / \text { day }\end{array}$ & Acne & Neg & Palpable nodule & $\begin{array}{l}\text { TSH } 0.011(\mathrm{nl} 0.36-3.5 \mu \mathrm{IU} / \mathrm{L}) \\
\text { Free T4 } 2.4(\mathrm{nl} 0.82-1.96 \mathrm{ng} / \mathrm{dL})\end{array}$ & None & 2 months \\
\hline$[10]$ & 38 & $\mathrm{~F}$ & $\begin{array}{l}3 \text { weeks; } \\
\text { unknown }\end{array}$ & Acne & Neg & Fever, rash, eosinophilia & $\begin{array}{l}\text { TSH } 0.02 \mu \mathrm{IU} / \mathrm{mL} \\
\text { Free T4 } 3.7 \mathrm{ng} / \mathrm{dL} \\
\text { Normal ranges not given }\end{array}$ & Prednisone & Unknown \\
\hline
\end{tabular}

M, male; F, female; Ab, anti-Tg and anti-TPO antibodies; Neg, negative; TSH, thyroid-stimulating hormone; T4, thyroxine; nl, normal.

5 months after drug discontinuation, except for 1 in which transient hypothyroidism developed.

The concentration of minocycline and/or its metabolites in the thyroid have been demonstrated by the observation of "black thyroid" in patients taking minocycline, and the histologic effect on the thyroid appears similar to that induced by amiodarone exposure [34]. Although further studies are needed to completely elucidate the mechanism of minocycline-induced thyroiditis, we propose that minocycline concentrates in the thyroid follicular cells where it and/or its metabolites are oxidized by TPO, leading to cytotoxic damage and the release of preformed TSH. This appears to be a self-limiting process that resolves after discontinuation of the drug. Treatment with antithyroid medications which inhibit TSH formation may not be warranted, and in the 2 reported cases, methimazole failed to hasten the resolution of thyroiditis. Similar to other known mechanisms of drug-induced thyroiditis, minocycline-induced thyroiditis is not dependent on the presence or development of thyroid autoimmunity. Minocycline causes non-autoimmune thyroiditis and may do so more frequently than previously appreciated. Exposure to minocycline should be considered in the differential of a patient presenting with thy- roiditis. If discovered, minocycline-associated thyroiditis should be treated similarly to other forms of drug-induced thyroiditis, by discontinuing minocycline, symptomatic management with $\beta$-blockade if indicated, and laboratory monitoring of thyroid function.

Our report is limited by its retrospective nature and single study site. Follow-up information was limited, especially as most patients had a resolution of their symptoms and did not return for further evaluation. Although we noted an association between minocycline use and the development of thyroiditis, we could not establish causality in this observational study. Further prospective studies are needed to determine the incidence of thyroiditis in patients taking minocycline as well as to investigate a potential mechanism.

Given the propensity of minocycline to cause other autoimmune syndromes, it is possible that it affects thyroid function via an underlying immune mechanism. However, in the absence of other symptoms, it is difficult to isolate the minocycline effect from autoimmune thyroiditis unrelated to drug exposure. Further controlled prospective studies are needed to address the development of autoimmune thyroiditis in patients taking minocycline. 
Nearly all adolescents are affected by some degree of acne, and in up to $20 \%$ the acne is moderate or severe [35]. Oral minocycline is the first-line therapy for moderate to severe acne and represents up to half of all oral antibiotics prescribed for this indication $[16,36]$. Estimates of adverse events occurring with minocycline use are as high as 72 per million prescriptions, compared to 13 per million prescriptions for doxycycline, another commonly prescribed tetracycline. Many of the adverse events associated with minocycline are mild gastrointestinal and vestibular disturbances; however, there are reports of fatal reactions including DRESS and hepatitis [37, 38]. Minocycline is known to concentrate in the thyroid, leading to "black thyroid," which was thought to be a benign finding. However, we have observed that minocycline can also lead to non-autoimmune thyroiditis in adolescents at any time during the treatment course. Although there is not enough evidence to recommend the routine monitoring of thyroid function, we do suggest that a history of minocycline exposure be elicited in any patient presenting with thyrotoxicosis while taking minocycline.

\section{Conclusion}

Long known to cause thyroid pigmentation, it is hypothesized that minocycline can also lead to non-autoimmune thyroiditis. Acne is a common condition in adolescents for which minocycline is utilized. Clinicians pre- scribing minocycline should be aware of its potential to cause thyroiditis and should counsel patients regarding the symptoms of thyrotoxicosis. Patients presenting with thyroiditis should also be queried about the history of minocycline use. Further studies are needed to determine the cause and frequency of minocycline-induced thyroiditis.

\section{Statement of Ethics}

The study was approved by the local ethics committee, the Institutional Review Board of Boston Children's Hospital. As this was a retrospective chart review, written informed consent from subjects was not required.

\section{Disclosure Statement}

The authors have no conflicts of interest to declare.

\section{Funding Sources}

K.M. was supported by NIH grant T32-DK007699.

\section{Author Contributions}

K.M. and J.S. conceptualized and designed the study. K.M. collected and analyzed the data and drafted the initial manuscript with A.C. All authors reviewed and approved the final version of the manuscript.

\section{References}

1 Elkayam O, Yaron M, Caspi D. Minocyclineinduced autoimmune syndromes: an overview. Semin Arthritis Rheum. 1999 Jun;28(6): 392-7.

2 Eisen D, Hakim MD. Minocycline-induced pigmentation. Incidence, prevention and management. Drug Saf. 1998 Jun;18(6):43140.

3 Attwood HD, Dennett X. A black thyroid and minocycline treatment. BMJ. 1976 Nov; 2(6044):1109-10.

4 Oertel YC, Oertel JE, Dalal K, Mendoza MG, Fadeyi EA. Black thyroid revisited: cytologic diagnosis in fine-needle aspirates is unlikely. Diagn Cytopathol. 2006 Feb;34(2):106-11.

5 Nishimoto K, Kumai Y, Murakami D, Yumoto E. A case of minocycline-induced black thyroid associated with papillary carcinoma. Ear Nose Throat J. 2016 Mar;95(3):E28-31.

6 Billano RA, Ward WQ, Little WP. Minocycline and black thyroid. JAMA. 1983 Apr; 249(14): 1887 .
7 Saul SH, Dekker A, Lee RE, Breitfeld V. The black thyroid. Its relation to minocycline use in man. Arch Pathol Lab Med. 1983 Apr; 107(4):173-7.

8 Hecht DA, Wenig BM, Sessions RB. Black thyroid: A collaborative series. Otolaryngol Head Neck Surg. 1999 Sep;121(3):293-6.

9 Brown RJ, Rother KI, Artman H, Mercurio MG, Wang R, Looney RJ, et al. Minocyclineinduced drug hypersensitivity syndrome followed by multiple autoimmune sequelae. Arch Dermatol. 2009 Jan;145(1):63-6.

10 Shaughnessy KK, Bouchard SM, Mohr MR, Herre JM, Salkey KS. Minocycline-induced drug reaction with eosinophilia and systemic symptoms (DRESS) syndrome with persistent myocarditis. J Am Acad Dermatol. 2010 Feb;62(2):315-8.

11 Pollock AJ, Seibert T, Allen DB. Severe and persistent thyroid dysfunction associated with tetracycline-antibiotic treatment in youth. J Pediatr. 2016 Jun;173:232-4.
12 Nelson ML, Levy SB. The history of the tetracyclines. Ann N Y Acad Sci. 2011 Dec;1241(1): 17-32.

13 Stephens CR, Conover LH, Hochstein FA, Regna PP, Pilgrim FJ, Brunings KJ, et al. Terramycin. VIII. structure of aureomycin and terramycin. J Am Chem Soc. 1952;74(19): 4976-7.

14 Grossman TH. Tetracycline antibiotics and resistance. Cold Spring Harb Perspect Med. 2016 Apr;6(4):a025387.

15 Bienenfeld A, Nagler AR, Orlow SJ. Oral Antibacterial Therapy for Acne Vulgaris: An Evidence-Based Review. Am J Clin Dermatol. 2017 Aug; 18(4):469-90.

16 Zaenglein AL, Pathy AL, Schlosser BJ, Alikhan A, Baldwin HE, Berson DS, et al. Guidelines of care for the management of acne vulgaris. J Am Acad Dermatol. 2016 May;74(5):945-73. e33.

17 Jonas M, Cunha BA. Minocycline. Ther Drug Monit. 1982;4(2):137-45. 
18 Smilack JD. The tetracyclines. Mayo Clin Proc. 1999 Jul;74(7):727-9.

19 Maubec E, Wolkenstein P, Loriot MA, Wechsler J, Mulot C, Beaune P, et al. Minocycline-induced DRESS: evidence for accumulation of the culprit drug. Dermatology. 2008; 216(3):200-4.

20 Benitz KF, Roberts GK, Yusa A. Morphologic effects of minocycline in laboratory animals. Toxicol Appl Pharmacol. 1967 Jul;11(1):15070.

21 Saito K, Jujio T, Hashizume I, Yamada T, Onaya T. Studies on goitrogenic action of minocycline and related compounds. Endocrinology. 1972 May;90(5):1192-201.

22 Taurog A, Dorris ML, Doerge DR. Minocycline and the thyroid: antithyroid effects of the drug, and the role of thyroid peroxidase in minocycline-induced black pigmentation of the gland. Thyroid. 1996 Jun;6(3): 211-9.

23 Doerge DR, Divi RL, Deck J, Taurog A. Mechanism for the anti-thyroid action of minocycline. Chem Res Toxicol. 1997 Jan;10(1):4958.

24 Miller BT, Lewis C, Bentz BG. Black thyroid resulting from short-term doxycycline use: case report, review of the literature, and discussion of implications. Head Neck. 2006 Apr;28(4):373-7.
25 Sabir S, Akhtar MF, Saleem A. Endocrine disruption as an adverse effect of non-endocrine targeting pharmaceuticals. Environ Sci Pollut Res Int. 2019 Jan;26(2):1277-86.

26 Bann DV, Goyal N, Crist H, Goldenberg D. Black thyroid. Ear Nose Throat J. 2014 OctNov;93(10-11):E54-5.

27 Martino E, Bartalena L, Bogazzi F, Braverman LE. The effects of amiodarone on the thyroid. Endocr Rev. 2001 Apr;22(2):240-54.

28 Carella C, Mazziotti G, Amato G, Braverman LE, Roti E. Clinical review 169: Interferon-arelated thyroid disease: pathophysiological, epidemiological, and clinical aspects. J Clin Endocrinol Metab. 2004 Aug;89(8):3656-61.

29 Miller KK, Daniels GH. Association between lithium use and thyrotoxicosis caused by silent thyroiditis. Clin Endocrinol (Oxf). 2001 Oct;55(4):501-8.

30 Dang AH, Hershman JM. Lithium-associated thyroiditis. Endocr Pract. 2002 May-Jun;8(3): 232-6.

31 Byun DJ, Wolchok JD, Rosenberg LM, Girotra M. Cancer immunotherapy - immune checkpoint blockade and associated endocrinopathies. Nat Rev Endocrinol. 2017 Apr; 13(4):195-207.

32 Makita N, Iiri T. Tyrosine kinase inhibitorinduced thyroid disorders: a review and hypothesis. Thyroid. 2013 Feb;23(2):151-9.
33 Benjamin RW, Calikoglu AS. Hyperthyroidism and lupus-like syndrome in an adolescent treated with minocycline for acne vulgaris. Pediatr Dermatol. 2007 May-Jun;24(3):2469.

34 Tacon L, Tan CT, Alvarado R, Gill AJ, Sywak M, Fulcher G. Drug-induced thyroiditis and papillary carcinoma in a minocycline-pigmented black thyroid gland. Thyroid. 2008 Jul;18(7):795-7.

35 Bhate K, Williams HC. Epidemiology of acne vulgaris. Br J Dermatol. 2013 Mar;168(3): 474-85.

36 Lee YH, Liu G, Thiboutot DM, Leslie DL, Kirby JS. A retrospective analysis of the duration of oral antibiotic therapy for the treatment of acne among adolescents: investigating practice gaps and potential costsavings. J Am Acad Dermatol. 2014 Jul; 71(1):70-6

37 Smith K, Leyden JJ. Safety of doxycycline and minocycline: a systematic review. Clin Ther. 2005 Sep;27(9):1329-42.

38 Lebrun-Vignes B, Kreft-Jais C, Castot A, Chosidow O; French Network of Regional Centers of Pharmacovigilance. Comparative analysis of adverse drug reactions to tetracyclines: results of a French national survey and review of the literature. Br J Dermatol. 2012 Jun;166(6):1333-41. 